DURNAI, R IS'IT
(Rekayasa Sistem dan Teknologi Informasi)
Vol.1 No.3 (2017) $250-238$ ISSN Media Elektronik : 2580-0760

\title{
Analisis Risiko Teknologi Informasi Menggunakan ISO 31000 pada Program HRMS
}

\author{
Stefan Agustinus ${ }^{\mathrm{a}}$, Adi Nugroho ${ }^{\mathrm{b}}$, Ariya Dwika Cahyono ${ }^{\mathrm{c}}$ \\ ${ }^{a}$ Program Studi Sistem Informasi, Fakultas Teknologi Informasi, Universitas Kristen Satya Wacana, s14agustinus@gmail.com

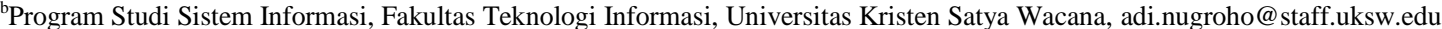 \\ 'Program Studi Sistem Informasi, Fakultas Teknologi Informasi, Universitas Kristen Satya Wacana, ariyadc@ @staff.uksw.edu
}

\begin{abstract}
The HRMS program is the central database of all matters relating to Human Resources Development of PT. XYZ. The existence of HRMS program is very important for the sustainability of the company, especially in the employment sector. Therefore, this HRMS program should be able to run optimally and consistently. A risk analysis is required to obtain documentation of the various possible risks that are in the vicinity of the HRMS program and the risk treatment required to minimize the likelihood of these risks arising. Risk analysis used at PT. XYZ is ISO 31000. The first stage used in this research is the stage of risk assessment which consisting of 3 stages, namely risk identification, risk analysis, and risk evaluation. The second stage is the stage of risk treatment. The results of this research are used as a tool for the stakeholders of the company to be able to arrange documentation related to company risk management in the future.
\end{abstract}

Keywords: Risk Analysis, International Organization for Standardization (ISO) 31000, Human Resources Management System (HRMS)

\begin{abstract}
Abstrak
Program HRMS merupakan database pusat dari segala hal yang berkaitan dengan Human Resources Development dari PT. XYZ. Keberadaan program HRMS ini tentu saja sangat penting bagi keberlangsungan perusahaan, terutama di sektor kepegawaian. Maka dari itu program HRMS ini harus bisa berjalan secara optimal dan konsisten. Dibutuhkan sebuah analisis risiko untuk mendapatkan dokumentasi terhadap berbagai macam kemungkinan risiko yang berada di sekitar dari program HRMS serta perlakuan risiko yang diperlukan untuk meminimalisir kemungkinan-kemungkinan risiko tersebut muncul. Analisis risiko yang digunakan pada PT. XYZ adalah ISO 31000. Tahapan pertama yang digunakan dalam penelitian ini adalah tahap penilaian risiko yang terdiri dari 3 tahapan, yaitu identifikasi risiko, analisis risiko, dan evaluasi risiko. Tahapan kedua adalah tahap perlakuan risiko. Hasil dari penelitian ini digunakan sebagai alat bantu bagi pemangku kebijakan dari perusahaan untuk dapat menyusun dokumentasi terkait dengan manajemen risiko perusahaan di kemudian hari.
\end{abstract}

Kata kunci: Analisis Risiko, International Organization for Standardization (ISO) 31000, Human Resources Management System (HRMS)

(C) 2017 Jurnal RESTI

\section{Pendahuluan}

PT. XYZ merupakan sebuah perusahaan yang bergerak di bidang usaha retail. Sebagai salah satu perusahaan yang cukup besar, PT. XYZ kemudian masih dibagibagi kembali ke dalam cabang-cabang berdasarkan beberapa kota besar yang ada di Indonesia. Salah satu cabang yang ada di PT. XYZ adalah cabang Head Office (HO). HO PT. XYZ berkedudukan di dua lokasi yang berbeda di Jakarta, yaitu yang pertama berlokasi di Kemayoran (HO Kemayoran) dan yang kedua berlokasi di Ancol (HO Ancol).
Sebagai kantor pusat, baik HO Kemayoran maupun HO Ancol tentu saja menjadi pusat dari aktivitas PT. XYZ itu sendiri. Di dalam HO ini juga masih dibagibagi kembali ke dalam 14 direktorat yang berbeda, salah satunya ialah direktorat Information Technology (IT) yang tentu saja adalah direktorat yang menangani semua persoalan yang berkaitan dengan teknologi informasi dari PT. XYZ.

Salah satu program yang digunakan PT. XYZ ialah HRMS (Human Resources Managemet System). Program ini dikembangkan oleh direktorat IT, divisi Software Development and Support 4, bagian Software Development II dan Software Support 2. Fungsi dari 
program HRMS ialah sebagai database pusat dari segala hal yang berkaitan dengan Human Resources Development (HRD). Keberadaan program HRMS ini tentu saja sangat penting bagi keberlangsungan perusahaan, terutama untuk sektor kepegawaian. Maka dari itu program HRMS ini harus bisa berjalan secara optimal dan konsisten.

Namun sama halnya dengan program atau sistem lainnya, HRMS tentu saja juga memiliki berbagai macam kemungkinan risiko yang bisa saja muncul setiap saat dan tentu saja dapat mengganggu bahkan hingga melumpuhkan kinerja sistem sehingga program tidak dapat berjalan secara optimal dan konsisten. Kemungkinan-kemungkinan risiko tersebut bisa saja datang dari beberapa macam faktor yang berada di sekitarnya. Berdasarkan dari permasalahan di atas inilah, maka dirasa perlu untuk melakukan sebuah penelitian yang berkaitan dengan analisis manajemen risiko dengan menggunakan ISO 31000. Tujuannya ialah dengan hasil penelitian ini nantinya dapat mendokumentasikan risiko-risiko yang dihadapi serta tindakan yang dilakukan untuk meminimalisir risiko terhadap program HRMS di PT. XYZ yang bisa saja muncul setiap saat pada aset-aset yang merupakan kesatuan dari program HRMS untuk dapat dilakukan pengendaliannya secara menyeluruh di masa yang akan datang.

\section{Tinjauan Pustaka}

Penelitian di Lembaga Penerbangan dan Antariksa Nasional (LAPAN) terkait dengan analisis risiko teknologi informasi menggunakan ISO 31000 ini dapat melaksanakan tahapan dan proses analisis risiko teknologi informasi website Space Weather Information and Forecast Services (SWIFTS). Penggunaan ISO 31000 terhadap teknologi informasi website SWIFTS ini dapat membantu mendokumentasikan tingkat risiko dan perlakuan terhadap risiko teknologi informasi website SWIFTS. [1]

Analisis risiko teknologi informasi menggunakan ISO 31000 dilakukan pada Document Management System (DMS) di PT. Jabar Telematika (JATEL) ini juga menganalisis risiko yang terjadi pada DMS arsip elektronik Aplikasi Dokumen Elektronik (ADEL) dan Naskah Dinas Elektronik (NADINE). Penggunaan ISO 31000 ini menghasilkan analisis manajemen risiko teknologi informasi pada DMS arsip elektronik ADEL dan NADINE [2]

Penelitian analisis risiko teknologi informasi menggunakan ISO 31000 juga dilakukan pada lembaga penelitian perguruan tinggi. Hasil dari penelitian tersebut adalah tersedianya sebuah katalog mengenai risiko teknologi informasi yang terdiri dari daftar risiko dan faktor-faktor yang berkontribusi atau memicu terjadinya peristiwa tertentu yang mengancam penggunaan teknologi informasi pada lembaga penelitian perguruan tinggi. [5]

Berdasarkan dari 3 penelitian sebelumnya ini menunjukan adanya hubungan dengan penelitian yang penulis lakukan mengenai kerangka serta metode untuk mengidentifikasi aset-aset teknologi informasi, kemungkinan-kemungkinan risiko yang ada, dampak yang dapat dimunculkan, penilaian dan pengevaluasian risiko, serta perlakuan risiko yang dapat dilakukan. Penulis akan melakukan sebuah penelitian yang berfokus untuk memberikan usulan perlakuan risiko untuk semua kemungkinan-kemungkinan risiko yang sewaktu-waktu bisa muncul, baik itu risiko yang sudah pernah dialami oleh perusahaan maupun risiko yang belum pernah dialami oleh perusahaan.

Analisis manajemen risiko adalah suatu kegiatan yang dilakukan pada tingkat pimpinan pelaksana, yaitu berupa kegiatan penemuan dan analisis sistematis atas kerugian yang mungkin saja dapat dihadapi oleh sebuah perusahaan, akibat suatu risiko serta cara pengendalian yang paling tepat untuk menangani kerugian yang dihubungkan dengan tingkat keuntungan perusahaan. [3]

Analisis risiko mempunyai beberapa tujuan, yaitu:

a. Tujuan sebelum mengalami kerugian, berupa efisiensi, meningkatkan kepercayaan, menanggulangi tanggung jawab pihak luar.

b. Tujuan setelah mengalami kerugian, berupa keberlangsungan operasi, mampu untuk tetap terus survive, stabilitas pendapatan dan pertumbuhan. [3]

Melakukan analisis manajemen risiko terhadap asetaset teknologi informasi pada sebuah perusahaan merupakan suatu hal yang penting. Karena setiap aset yang dimiliki hingga semua aktivitas yang ada di dalam suatu perusahaan pasti memiliki risiko yang bisa saja muncul setiap saat tanpa bisa diprediksi sebelumnya jika tidak dianalisis oleh perusahaan yang berkaitan.

\section{Metodologi Penelitian}

ISO 31000 merupakan standar yang berkaitan dengan manajemen risiko yang dikodifikasi oleh International Organization for Standardization (ISO). Tujuan dari ISO sendiri adalah untuk memberikan prinsip-prinsip dan pedoman untuk manajemen risiko yang diakui secara universal. [1]

Penelitian ini akan dilakukan dengan menggunakan 2 tahapan yang telah disesuaikan dengan proses menejemen risiko dari International Organization for Standardization (ISO 31000:2009) di mana setiap informasi yang dibutuhkan dalam penelitian ini didapatkan dengan cara melalui wawancara terhadap sumber-sumber internal dari PT. XYZ. 
Tahapan yang pertama adalah Risk Assesment (Penilaian Risiko). Proses ini terdiri dari 3 tahapan, yaitu Risk Identification (Identifikasi Risiko), Risk Analyst (Analisis Risiko), dan Risk Evaluation (Evaluasi Risiko). Risk assesment atau penilaian risiko merupakan proses penentuan risiko yang berpotensi mempengaruhi organisasi dalam mencapai tujuannya. Risk analyst atau analisis risiko merupakan upaya untuk memahami risiko secara lebih mendalam. Sementara Risk Evaluation atau evaluasi risiko merupakan proses melakukan evaluasi terhadap tingkat kegawatan masing-masing risiko menggunakan kriteria yang telah ditentukan. [1]

Untuk tahapan yang kedua adalah Risk Treatment (Perlakuan Risiko). Tahapan ini meliputi upaya untuk menyeleksi pilihan-pilihan yang dapat mengurangi atau bahkan meniadakan dampak serta kemungkinan terjadinya risiko kemudian menerapkan pilihan-pilihan tersebut. [1]

Penelitian ini juga akan menggunakan metode Case Studies Research. Zainal A. Hasibuan, PhD (2007) mengemukakan bahwa metode Case Studies Research merupakan penelitian yang memusatkan perhatian pada suatu kasus tertentu dengan menggunakan individu atau kelompok sebagai bahan studinya. Penggunaan metode Case Studies Research ini biasanya difokuskan untuk menggali mengumpulkan data yang lebih dalam terhadap obyek yang diteliti untuk dapat menjawab permasalahan yang sedang terjadi. [4]

Penggunaan individu atau kelompok sebagai objek studi ini bertujuan agar peneliti bisa mendapatkan data yang peneliti butuhkan dan data penelitian yang didapatkan tersebut adalah data primer. Penelitian Case Studies Research datanya harus berupa data primer. Data ini dapat dikumpulkan dalam bentuk dokumen-dokumen yang telah divalidasi dan dilakukan verifikasi konfirmasi data ke primary source-nya. Zainal A. Hasibuan, PhD (2007) juga menambahkan bahwa sumber data yang diambil dari tesis atau disertasi tidak dapat digunakan karena data tersebut bukan data primer melainkan data tertier karena diambil dari data lain yang kemudian diolah. [4]

\section{Hasil dan Pembahasan}

\subsection{Tahap Penilaian Risiko}

Proses tahap penilaian risiko pada program HRMS ini akan terdiri 3 tahapan, yaitu tahap identifikasi risiko, tahap analisis risiko, dan tahap evaluasi risiko.

\subsubsection{Identifikasi Risiko}

Identifikasi aset HRMS

Tahapan identifikasi aset-aset yang terkait dengan HRMS dilakukan dengan melalui proses wawancara serta observasi kepada karyawan dari bagian Software Development II dan Software Support 2. Detail asetaset yang terkait dengan HRMS dapat dilihat pada Tabel 1.

Tabel 1. Tabel Identifikasi Aset HRMS

\begin{tabular}{lll}
\hline $\begin{array}{c}\text { Komponen Sistem } \\
\text { Informasi }\end{array}$ & Aset HRMS \\
\hline Data & a) & Data Recruiting \\
& b) & Data Hiring \\
& c) & Data Administration and Benefits \\
& d) & Data Time and Attendance \\
& e) & Data Training and Administration \\
& f) & - Data Leave and Permission \\
\hline Software & Human Resource Management & Hun \\
\hline Hardware & a) & Personal Computer (PC) \\
& b) & Server Database \\
& c) & Server Web Service \\
& d) & Server Remote Desktop Protocol \\
& (RDP) \\
& e) & Server Load Balancer \\
& f) & Server Compelant \\
& g) & Switch Bokade 300 \\
& h) & Kabel Fiber Optik \\
& i) & Kabel Unshielded Twisted Pair \\
& (UTP) \\
& j) & RJ 45 \\
\hline &
\end{tabular}

\section{Identifikasi kemungkinan risiko}

Setelah melakukan identifikasi aset, hal yang perlu diidentifikasi selanjutnya adalah kemungkinankemungkinan risiko yang berada di sekitar dari asetaset yang terkait dengan program HRMS. Kemungkinan-kemungkinan risiko tersebut dapat dilihat pada Tabel 2.

Tabel 2. Tabel Identifikasi Kemungkinan Risiko

\begin{tabular}{ll}
\hline ID & Kemungkinan Risiko \\
\hline KR01 & Data corrupt \\
KR02 & Kegagalan backup/generate data \\
KR03 & $\begin{array}{l}\text { Kegagalan proses pemeliharaan dan continue } \\
\text { development }\end{array}$ \\
KR04 & Software tidak dapat meningkatkan kualitas kinerja \\
& perusahaan \\
KR05 & Web service mati secara tiba-tiba \\
KR06 & Kesalahan pembuatan fungsi pada program \\
KR07 & Hacking terhadap jaringan \\
KR08 & Memori penuh \\
KR09 & Server down \\
KR10 & Koneksi jaringan terputus \\
KR11 & Kerusakan hardware \\
KR12 & Listrik padam \\
KR13 & Overheat \\
KR14 & Overload \\
KR15 & Penyelesaian program yang tidak tepat waktu \\
KR16 & Dokumentasi program yang tidak lengkap \\
KR17 & Petunjuk penggunaan program yang susah dipahami \\
KR18 & Penyelesaian program yang tidak tepat waktu \\
KR19 & User interface rumit dan susah dipahami \\
KR20 & Muncul anomali proses di lapangan yang tidak dapat \\
& diatasi oleh program \\
KR21 & Kurangnya SDM secara kualitas/kuantitas \\
KR22 & Pencurian perangkat/data \\
KR23 & Banjir \\
KR24 & Gempa bumi \\
KR25 & Kebakaran \\
KR26 & Petir \\
&
\end{tabular}




\section{Identifikasi dampak risiko}

Tahapan identifikasi selanjutnya adalah identifikasi dampak risiko. Proses ini mencoba untuk mengidentifikasi dampak seperti apa yang akan dialami oleh program HRMS jika kemungkinankemungkinan risiko yang sudah diidentifikasi sebelumnya terjadi. Detail dari identifikasi dampak risiko terdapat pada Tabel 3.

Tabel 3. Tabel Identifikasi Dampak Risiko

\begin{tabular}{|c|c|c|}
\hline ID & $\begin{array}{l}\text { Kemungkinan } \\
\text { Risiko }\end{array}$ & Dampak \\
\hline KR01 & Data corrupt & $\begin{array}{l}\text { Data kepegawaian PT. XYZ rusak } \\
\text { dan tidak dapat diakses. } \\
\text { Terjadi masalah terkait dengan } \\
\text { presensi kehadiran, lembur, dan } \\
\text { gaji dari karyawan. }\end{array}$ \\
\hline KR02 & $\begin{array}{l}\text { Kegagalan } \\
\text { backup/generate } \\
\text { data }\end{array}$ & $\begin{array}{l}\text { Maintenance plan tidak dapat } \\
\text { berjalan. }\end{array}$ \\
\hline KR03 & $\begin{array}{l}\text { Kegagalan } \\
\text { proses } \\
\text { pemeliharaan } \\
\text { dan continue } \\
\text { development }\end{array}$ & $\begin{array}{l}\text { Program mengalami penurunan } \\
\text { performa secara perlahan-perlahan. } \\
\text { Teknologi yang digunakan pada } \\
\text { program tidak berkembang. }\end{array}$ \\
\hline KR04 & $\begin{array}{l}\text { Program tidak } \\
\text { dapat } \\
\text { meningkatkan } \\
\text { kualitas kinerja } \\
\text { perusahaan }\end{array}$ & $\begin{array}{l}\text { Kualitas kinerja HRD perusahaan } \\
\text { tidak dapat berkembang secara } \\
\text { optimal. }\end{array}$ \\
\hline KR05 & $\begin{array}{l}\text { Web service mati } \\
\text { secara tiba-tiba }\end{array}$ & $\begin{array}{l}\text { Gagal melakukan akses ke program } \\
\text { HRMS dan database utama. }\end{array}$ \\
\hline KR06 & $\begin{array}{l}\text { Proses } \\
\text { maintenance } \\
\text { tidak terjadwal }\end{array}$ & $\begin{array}{l}\text { Mengganggu aktifitas pada } \\
\text { program HRMS dan database } \\
\text { utama. }\end{array}$ \\
\hline KR07 & $\begin{array}{l}\text { Hacking } \\
\text { terhadap jaringan }\end{array}$ & $\begin{array}{l}\text { Pencurian data-data penting } \\
\text { perusahaan. } \\
\text { Penyalahgunaan sumber daya pada } \\
\text { jaringan. }\end{array}$ \\
\hline KR08 & Overcapacity & $\begin{array}{l}\text { Inputan data baru yang berkaitan } \\
\text { dengan kepegawaian PT. XYZ } \\
\text { gagal ditampung oleh database } \\
\text { utama. }\end{array}$ \\
\hline KR09 & Server down & $\begin{array}{l}\text { Sulit/gagal melakukan akses ke } \\
\text { program HRMS dan database } \\
\text { utama. }\end{array}$ \\
\hline KR10 & $\begin{array}{l}\text { Koneksi jaringan } \\
\text { terputus }\end{array}$ & $\begin{array}{l}\text { Gagal melakukan akses ke program } \\
\text { HRMS dan database utama. }\end{array}$ \\
\hline KR11 & $\begin{array}{l}\text { Kerusakan } \\
\text { hardware }\end{array}$ & $\begin{array}{l}\text { Tidak dapat melakukan akses ke } \\
\text { program HRMS dan database } \\
\text { utama. }\end{array}$ \\
\hline KR12 & Listrik padam & $\begin{array}{l}\text { Aktifitas perusahaan tidak dapat } \\
\text { berjalan. }\end{array}$ \\
\hline KR13 & Overheat & $\begin{array}{l}\text { Kinerja hardware tersendat dan } \\
\text { tidak maksimal. } \\
\text { Rusaknya hardware karena harus } \\
\text { menanggung suhu ekstrim secara } \\
\text { terus-menerus. }\end{array}$ \\
\hline KR14 & Overload & $\begin{array}{l}\text { Log database dan Log temp } \\
\text { database penuh. } \\
\text { Terjadinya bottleneck. }\end{array}$ \\
\hline KR15 & $\begin{array}{l}\text { Dokumentasi } \\
\text { program yang } \\
\text { tidak lengkap }\end{array}$ & $\begin{array}{l}\text { Menyulitkan programmer dalam } \\
\text { pengembangan program. } \\
\text { Kesalahan pembuatan fungsi pada } \\
\text { program. }\end{array}$ \\
\hline KR16 & $\begin{array}{l}\text { Kesalahan } \\
\text { pembuatan } \\
\text { fungsi pada } \\
\text { program }\end{array}$ & Program tidak tepat guna. \\
\hline
\end{tabular}

\begin{tabular}{|c|c|c|}
\hline ID & $\begin{array}{l}\text { Kemungkinan } \\
\text { Risiko }\end{array}$ & Dampak \\
\hline KR17 & $\begin{array}{l}\text { Tampilan } \\
\text { program tidak } \\
\text { user friendly }\end{array}$ & $\begin{array}{l}\text { Menyulitkan user dalam memahami } \\
\text { cara penggunaan program. }\end{array}$ \\
\hline KR18 & $\begin{array}{l}\text { Penyelesaian } \\
\text { program yang } \\
\text { tidak tepat waktu }\end{array}$ & $\begin{array}{l}\text { Penyelesaian permasalahan tidak } \\
\text { tepat waktu. }\end{array}$ \\
\hline KR19 & $\begin{array}{l}\text { Petunjuk } \\
\text { penggunaan } \\
\text { program yang } \\
\text { susah dipahami }\end{array}$ & $\begin{array}{l}\text { Menyulitkan user dalam memahami } \\
\text { cara penggunaan program. }\end{array}$ \\
\hline KR20 & $\begin{array}{lr}\text { Muncul } & \text { anomali } \\
\text { proses } & \text { di } \\
\text { lapangan } & \text { yang } \\
\text { tidak } & \text { dapat } \\
\text { diatasi } & \text { oleh } \\
\text { program } & \end{array}$ & $\begin{array}{l}\text { Anomali proses yang muncul harus } \\
\text { dijalankan secara manual. }\end{array}$ \\
\hline KR21 & $\begin{array}{l}\text { Kurangnya SDM } \\
\text { secara } \\
\text { kualitas/kuantitas }\end{array}$ & $\begin{array}{l}\text { Penyelesaian program pendukung } \\
\text { yang tidak tepat waktu. } \\
\text { Kesulitan dalam pembagian kerja. }\end{array}$ \\
\hline KR22 & $\begin{array}{l}\text { Pencurian } \\
\text { perangkat/data }\end{array}$ & $\begin{array}{l}\text { Kerugian secara finansial/informasi } \\
\text { berkaitan dengan kerahasiaan } \\
\text { perusahaan. }\end{array}$ \\
\hline KR23 & Banjir & $\begin{array}{lcr}\text { Kerusakan } & \text { infrastruktur } & \text { dan } \\
\text { menghambat } & \text { aktivitas } & \text { bisnis } \\
\text { perusahaan. } & & \end{array}$ \\
\hline KR24 & Gempa bumi & $\begin{array}{lcr}\text { Kerusakan } & \text { infrastruktur } & \text { dan } \\
\text { menghentikan } & \text { aktivitas } & \text { bisnis } \\
\text { perusahaan. } & & \end{array}$ \\
\hline KR25 & Kebakaran & $\begin{array}{lcr}\text { Kerusakan } & \text { infrastruktur } & \text { dan } \\
\text { menghentikan } & \text { aktivitas } & \text { bisnis } \\
\text { perusahaan. } & & \end{array}$ \\
\hline KR26 & Petir & $\begin{array}{l}\text { Kerusakan } \\
\text { perusahaan. }\end{array}$ \\
\hline
\end{tabular}

\subsubsection{Analisis Risiko}

Setelah menyelesaikan tahap identifikasi, tahap selanjutnya adalah tahap analisis risiko. pada proses ini akan dilakukan penilaian terhadap kemungkinankemungkinan risiko yang sudah teridentifikasi. Penentuan nilai ini akan dilakukan berdasarkan kemungkinan (likelihood) dan dampak (impact) yang terdapat pada Tabel 4 dan Tabel 5.

Tabel 4. Tabel Nilai pada Likelihood

\begin{tabular}{|c|c|c|c|}
\hline \multicolumn{2}{|c|}{ Likelihood } & \multirow[t]{2}{*}{ Deskripsi } & \multirow{2}{*}{$\begin{array}{l}\text { Frekuensi } \\
\text { per } \\
\text { kejadian }\end{array}$} \\
\hline Nilai & Kriteria & & \\
\hline 1 & Rare & $\begin{array}{l}\text { Risiko tersebut hampir } \\
\text { tidak pernah terjadi }\end{array}$ & $>5$ tahun \\
\hline 2 & Unlikely & $\begin{array}{l}\text { Risiko tersebut jarang } \\
\text { terjadi }\end{array}$ & $2-5$ tahun \\
\hline 3 & Possible & $\begin{array}{l}\text { Risiko tersebut kadang } \\
\text { terjadi }\end{array}$ & $1-2$ tahun \\
\hline 4 & Likely & $\begin{array}{l}\text { Risiko tersebut sering } \\
\text { terjadi }\end{array}$ & $7-12$ bulan \\
\hline 5 & Certain & $\begin{array}{l}\text { Risiko } \\
\text { terjadi }\end{array}$ & $1-6$ bulan \\
\hline
\end{tabular}

Tabel 5. Tabel Nilai pada Impact

\begin{tabular}{lll}
\hline Nilai & $\begin{array}{c}\text { Impact } \\
\text { Kriteria }\end{array}$ & \multicolumn{1}{c}{ Deskripsi } \\
\hline 1 & Insignificant & $\begin{array}{l}\text { Risiko tersebut tidak mengganggu } \\
\text { proses bisnis yang ada dan jalannya } \\
\text { aktivitas perusahaan. }\end{array}$ \\
& Minor & $\begin{array}{l}\text { Risiko tersebut mulai sedikit } \\
\text { menghambat jalannya aktivitas } \\
\text { perusahaan. }\end{array}$ \\
\hline
\end{tabular}




\begin{tabular}{lll}
\hline Nilai & $\begin{array}{c}\text { Impact } \\
\text { Kriteria }\end{array}$ & \multicolumn{2}{c}{ Deskripsi } \\
\hline 3 & Moderate & $\begin{array}{l}\text { Risiko tersebut menghambat } \\
\text { sebagian jalannya aktivitas } \\
\text { perusahaan. } \\
\text { Risiko tersebut mulai mengganggu } \\
\text { proses bisnis yang ada dan } \\
\text { menghambat hampir seluruh } \\
\text { jalannya aktivitas perusahaan. } \\
\text { Risiko tersebut sangat mengganggu } \\
\text { proses bisnis yang ada dan } \\
\text { menghentikan jalannya aktivitas } \\
\text { perusahaan secara menyeluruh. }\end{array}$ \\
& Catastrophic &
\end{tabular}

Setelah melakukan penentuan nilai pada kemungkinan (likelihood) di Tabel 4 dan pada dampak (impact) di Tabel 5, selanjutnya adalah memulai penilaian terhadap kemungkinan-kemungkinan risiko yang berada di sekitar dari aset-aset yang terkait dengan program HRMS yang sudah teridentifikasi sebelumnya. Detail dari penilaian kemungkinankemungkinan risiko dapat dilihat pada Tabel 6.

Tabel 6. Tabel Penilaian Likelihood dan Impact pada Kemungkinan Risiko

\begin{tabular}{|c|c|c|c|}
\hline ID & Kemungkinan Risiko & Likelihood & Impact \\
\hline KR01 & Data corrupt & 1 & 5 \\
\hline KR02 & $\begin{array}{l}\text { Kegagalan backup/generate } \\
\text { data }\end{array}$ & 2 & 2 \\
\hline KR03 & $\begin{array}{l}\text { Kegagalan proses pemeliharaan } \\
\text { dan continue development }\end{array}$ & 1 & 3 \\
\hline KR04 & $\begin{array}{l}\text { Program } \quad \text { tidak } \\
\text { meningkatkan } \\
\text { perusahalitas }\end{array}$ & 1 & 4 \\
\hline KR05 & $\begin{array}{l}\text { Web service mati secara tiba- } \\
\text { tiba }\end{array}$ & 5 & 2 \\
\hline KR06 & $\begin{array}{l}\text { Proses maintenance tidak } \\
\text { terjadwal }\end{array}$ & 5 & 1 \\
\hline KR07 & Hacking terhadap jaringan & 1 & 4 \\
\hline KR08 & Overcapacity & 1 & 3 \\
\hline KR09 & Server down & 5 & 2 \\
\hline KR10 & Koneksi jaringan terputus & 2 & 5 \\
\hline KR11 & Kerusakan hardware & 1 & 4 \\
\hline KR12 & Listrik padam & 4 & 5 \\
\hline KR13 & Overheat & 1 & 1 \\
\hline KR14 & Overload & 5 & 3 \\
\hline KR15 & $\begin{array}{l}\text { Dokumentasi program yang } \\
\text { tidak lengkap }\end{array}$ & 5 & 2 \\
\hline KR16 & $\begin{array}{l}\text { Kesalahan pembuatan fungsi } \\
\text { pada program }\end{array}$ & 3 & 3 \\
\hline KR17 & $\begin{array}{l}\text { Tampilan program tidak user } \\
\text { friendly }\end{array}$ & 4 & 2 \\
\hline KR18 & $\begin{array}{l}\text { Penyelesaian program yang } \\
\text { tidak tepat waktu }\end{array}$ & 2 & 3 \\
\hline KR19 & $\begin{array}{l}\text { Petunjuk penggunaan program } \\
\text { yang susah dipahami }\end{array}$ & 1 & 2 \\
\hline KR20 & $\begin{array}{l}\text { Muncul anomali proses di } \\
\text { lapangan yang tidak dapat } \\
\text { diatasi oleh program }\end{array}$ & 4 & 1 \\
\hline KR21 & $\begin{array}{l}\text { Kurangnya SDM secara } \\
\text { kualitas/kuantitas }\end{array}$ & 5 & 1 \\
\hline KR22 & Pencurian perangkat/data & 1 & 3 \\
\hline KR23 & Banjir & 4 & 3 \\
\hline KR24 & Gempa bumi & 1 & 5 \\
\hline $\mathrm{KR} 25$ & Kebakaran & 1 & 5 \\
\hline KR26 & Petir & 1 & 4 \\
\hline
\end{tabular}

\subsubsection{Evaluasi Risiko}

Pada tahapan evaluasi risiko ini, kemungkinankemungkinan risiko yang sudah diidentifikasi serta dianalisis sebelumnya akan dimasukan ke dalam sebuah matrik evaluasi risiko berdasarkan kemungkinan (likelihood) dan dampak (impact).

Pembentukan matrik evaluasi risiko didapat berdasarkan dari parameter evaluasi risiko yang sudah ditentukan. Secara lebih detail, parameter evaluasi risiko dapat dilihat pada Tabel 7 sementara untuk matrik evaluasi risiko berdasarkan kemungkinan (likelihood) dan dampak (impact) dapat dilihat pada Tabel 8.

\begin{tabular}{lll} 
& Tabel 7. Tabel Parameter Evaluasi Risiko \\
\hline Likelihood & Impact & Level of risk \\
\hline Rare & Insignificant & Low \\
Rare & Minor & \\
Rare & Moderate & \\
Unlikely & Insignificant & \\
Unlikely & Minor & \\
Possible & Insignificant & Medium \\
\hline Rare & Major & \\
Rare & Catastrophic & \\
Unlikely & Moderate & \\
Unlikely & Major & \\
Unlikely & Catastrophic & \\
Possible & Minor & \\
Possible & Moderate & \\
Possible & Major & \\
Likely & Insignificant & \\
Likely & Minor & \\
Likely & Moderate & \\
Certain & Insignificant & \\
Certain & Minor & \\
\hline Possible & Catastrophic & \\
Likely & Major & \\
Likely & Catastrophic & \\
Certain & Moderate & \\
Certain & Major & \\
Certain & Catastrophic & \\
\hline
\end{tabular}

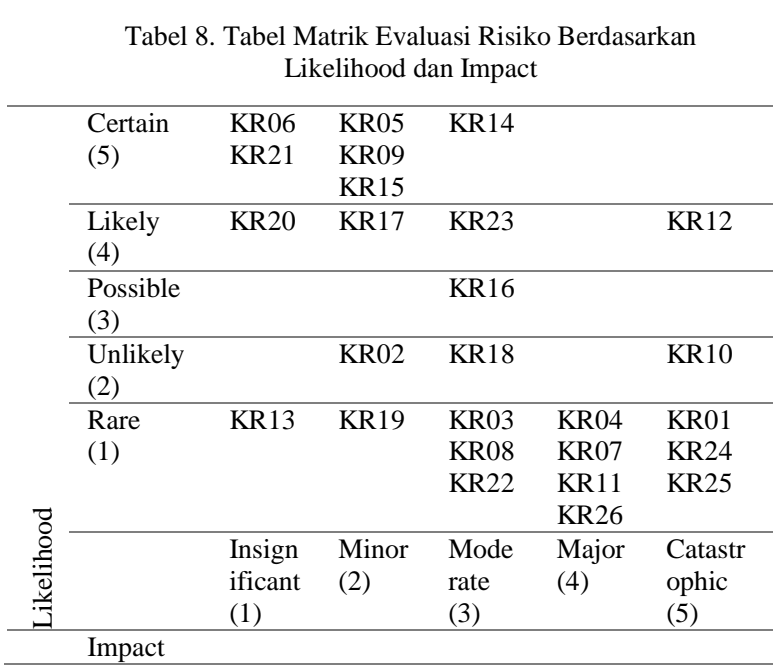

Setelah kemungkinan-kemungkinan risiko dimasukan ke dalam matrik evaluasi berdasarkan kemungkinan (likelihood) dan dampak (impact), baru kemudian 
dievaluasi seperti pada Tabel 9 di bawah. tidak dapat diatasi oleh program, kurangnya SDM Kemungkinan risiko disusun berdasarkan dari level of secara kualitas/kuantitas, banjir, gempa bumi, risk dengan tingkatan high hingga low.

Tabel 9. Tabel Evaluasi Kemungkinan Risiko Berdasarkan Likelihood dan Impact serta Level of Risk

\begin{tabular}{|c|c|c|c|c|}
\hline ID & Kemungkinan Risiko & $\begin{array}{l}\text { Likeli } \\
\text { hood }\end{array}$ & $\begin{array}{l}\text { Imp } \\
\text { act }\end{array}$ & $\begin{array}{l}\text { Level of } \\
\text { risk }\end{array}$ \\
\hline KR12 & Listrik padam & 4 & 5 & High \\
\hline KR14 & Overload & 5 & 3 & High \\
\hline KR01 & Data corrupt & 1 & 5 & Medium \\
\hline KR04 & $\begin{array}{l}\text { Program tidak dapat } \\
\text { meningkatkan kualitas } \\
\text { kinerja perusahaan }\end{array}$ & 1 & 4 & Medium \\
\hline KR05 & $\begin{array}{l}\text { Web service mati secara } \\
\text { tiba-tiba }\end{array}$ & 5 & 2 & Medium \\
\hline KR06 & $\begin{array}{l}\text { Proses maintenance } \\
\text { yang tidak terjadwal }\end{array}$ & 5 & 1 & Medium \\
\hline KR07 & $\begin{array}{l}\text { Hacking } \quad \text { terhadap } \\
\text { jaringan }\end{array}$ & 1 & 4 & Medium \\
\hline KR09 & Server down & 5 & 2 & Medium \\
\hline KR10 & $\begin{array}{l}\text { Koneksi jaringan } \\
\text { terputus }\end{array}$ & 2 & 5 & Medium \\
\hline KR11 & Kerusakan hardware & 1 & 4 & Medium \\
\hline KR15 & $\begin{array}{l}\text { Dokumentasi program } \\
\text { yang tidak lengkap }\end{array}$ & 5 & 2 & Medium \\
\hline KR16 & $\begin{array}{l}\text { Kesalahan pembuatan } \\
\text { fungsi pada program }\end{array}$ & 3 & 3 & Medium \\
\hline KR17 & $\begin{array}{l}\text { User interface rumit dan } \\
\text { susah dipahami }\end{array}$ & 4 & 2 & Medium \\
\hline KR18 & $\begin{array}{l}\text { Penyelesaian program } \\
\text { yang tidak tepat waktu }\end{array}$ & 2 & 3 & Medium \\
\hline KR20 & $\begin{array}{l}\text { Muncul anomali proses } \\
\text { di lapangan yang tidak } \\
\text { dapat diatasi oleh } \\
\text { program }\end{array}$ & 4 & 1 & Medium \\
\hline KR21 & $\begin{array}{l}\text { Kurangnya SDM secara } \\
\text { kualitas/kuantitas }\end{array}$ & 5 & 1 & Medium \\
\hline KR23 & Banjir & 4 & 3 & Medium \\
\hline $\mathrm{KR} 24$ & Gempa bumi & 1 & 5 & Medium \\
\hline KR25 & Kebakaran & 1 & 5 & Medium \\
\hline KR26 & Petir & 1 & 4 & Medium \\
\hline KR02 & $\begin{array}{l}\text { Kegagalan } \\
\text { backup/generate data }\end{array}$ & 2 & 2 & Low \\
\hline KR03 & $\begin{array}{l}\text { Kegagalan proses } \\
\text { pemeliharaan dan } \\
\text { continue development }\end{array}$ & 1 & 3 & Low \\
\hline KR08 & Memori penuh & 1 & 3 & Low \\
\hline KR13 & Overheat & 1 & 1 & Low \\
\hline KR19 & $\begin{array}{l}\text { Petunjuk penggunaan } \\
\text { program yang susah } \\
\text { dipahami }\end{array}$ & 1 & 2 & Low \\
\hline KR22 & $\begin{array}{l}\text { Pencurian } \\
\text { perangkat/data }\end{array}$ & 1 & 3 & Low \\
\hline
\end{tabular}

Berdasarkan dari Tabel 9 di atas, dapat dilihat jika 2 (listrik padam dan overload) dari 26 kemungkinan risiko yang ada memiliki level of risk dengan tingkatan high, 18 (data corrupt, program tidak dapat meningkatkan kualitas kinerja perusahaan, web service mati secara tiba-tiba, proses maintenance yang tidak terjadwal, hacking terhadap jaringan, server down, koneksi jaringan terputus, kerusakan hardware, dokumentasi program yang tidak lengkap, kesalahan pembuatan fungsi pada program, user interface rumit dan susah dipahami, penyelesaian program yang tidak tepat waktu, muncul anomali proses di lapangan yang kebakaran, dan petir) dari 26 kemungkinan risiko yang ada memiliki level of risk dengan tingkatan medium, dan 6 (kegagalan backup/generate data, kegagalan proses pemeliharaan dan continue development, memori penuh, overheat, petunjuk penggunaan program yang susah dipahami, dan pencurian perangkat/data) dari 26 kemungkinan risiko yang ada memiliki level of risk dengan tingkatan low.

\subsection{Tahap Perlakuan Risiko}

Pada tahapan ini, semua kemungkinan-kemungkinan risiko yang berada di sekitar dari aset-aset yang terkait dengan program HRMS akan diberikan usulan-usulan dalam memperlakukan kemungkinan-kemungkinan risiko tersebut dengan harapan bahwa usulan-usulan berikut ini dapat meminimalisir kemungkinan munculnya risiko-risiko tersebut sehingga program HRMS dapat berjalan secara optimal atau meminimalisir kerugian yang akan didapat oleh perusahaan ketika risiko-risiko tersebut muncul. Usulan perlakuan risiko disusun berdasarkan dari level of risk dengan tingkatan high hingga low. Detail dari usulan-usulan perlakuan risiko dapat dilihat pada Tabel 10.

\begin{tabular}{|c|c|c|c|}
\hline ID & $\begin{array}{l}\text { Kemungkin } \\
\text { an Risiko }\end{array}$ & $\begin{array}{l}\text { Level } \\
\text { resiko }\end{array}$ & Perlakuan Risiko \\
\hline KR05 & $\begin{array}{l}\text { Listrik } \\
\text { padam }\end{array}$ & High & $\begin{array}{l}\text { Penyediaan generator set } \\
\text { dan UPS (Uninterruptible } \\
\text { Power Supply) dengan } \\
\text { daya yang disesuaikan } \\
\text { terhadap kebutuhan } \\
\text { seluruh perusahaan. } \\
\text { Menggunakan } 2 \text { (dua) atau } \\
\text { lebih sumber listrik dari } \\
\text { gardu listrik yang } \\
\text { dibedakan. }\end{array}$ \\
\hline KR08 & Overload & High & $\begin{array}{l}\text { Menyusun jadwal } \\
\text { pengecekan dalam } 1 \text { hari } \\
\text { secara berkala terhadap db } \\
\text { log, temp db log, CPU } \\
\text { usage, dan RAM usage } \\
\text { dari program HRMS dan } \\
\text { database utama. } \\
\text { Melakukan refresh } \\
\text { terhadap db log, temp db } \\
\text { log, CPU usage, dan RAM } \\
\text { usage dari program HRMS } \\
\text { dan database utama. } \\
\text { Menambah personil di } \\
\text { bagian database analyst } \\
\text { agar dapat lebih sigap } \\
\text { dalam mengatasi risiko } \\
\text { tersebut. }\end{array}$ \\
\hline
\end{tabular}


Stefan Agustinus, Adi Nugroho, Arya Dwika Cahyono

Jurnal RESTI (Rekayasa Sistem dan Teknologi Informasi) Vol . 1 No. 3 (2017) 250 - 258

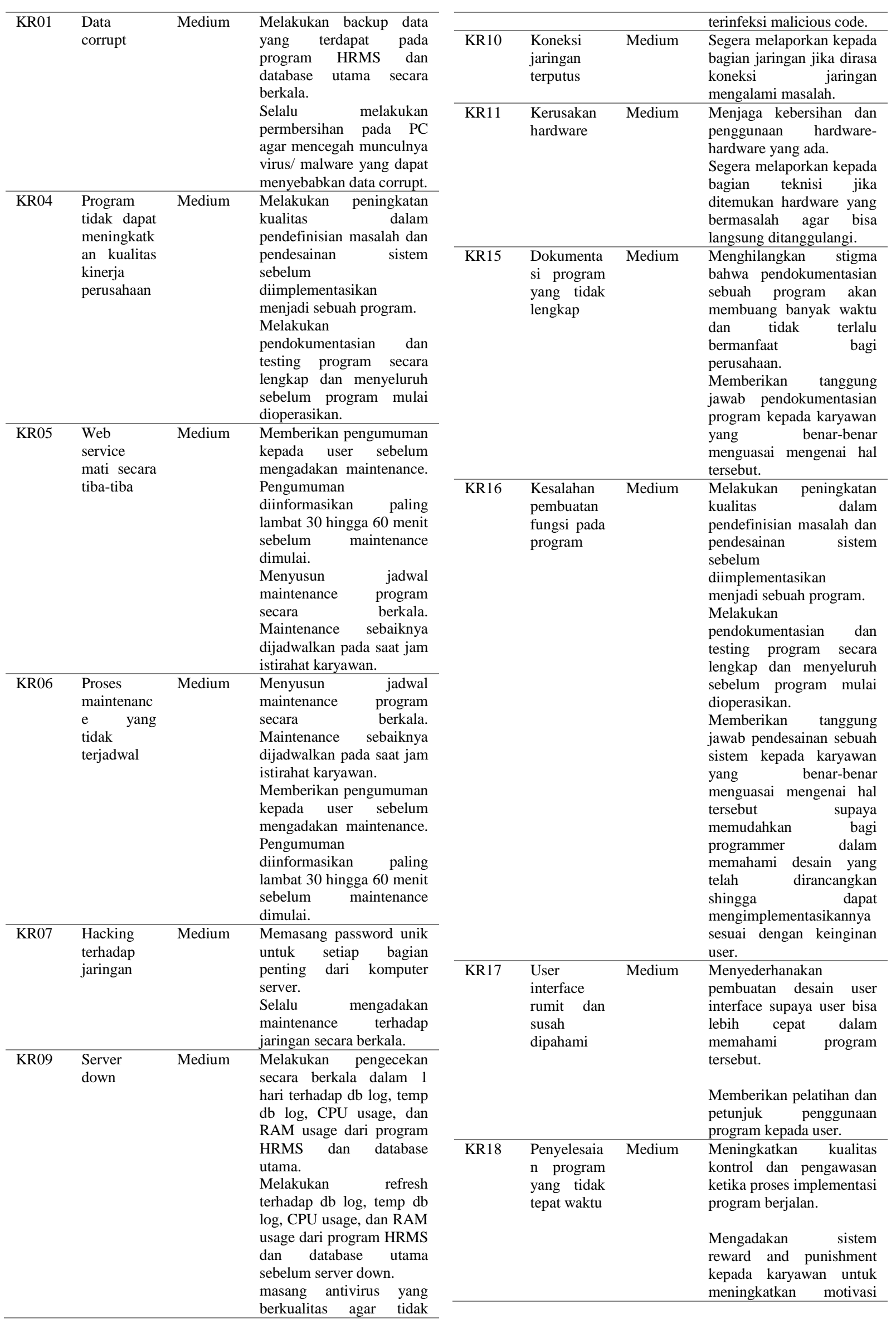

Jurnal RESTI (Rekayasa Sistem dan Teknologi Informasi) Vol . 1 No. 3 (2017) 250 - 258 
Stefan Agustinus, Adi Nugroho, Arya Dwika Cahyono

Jurnal RESTI (Rekayasa Sistem dan Teknologi Informasi) Vol . 1 No. 3 (2017) 250 - 258

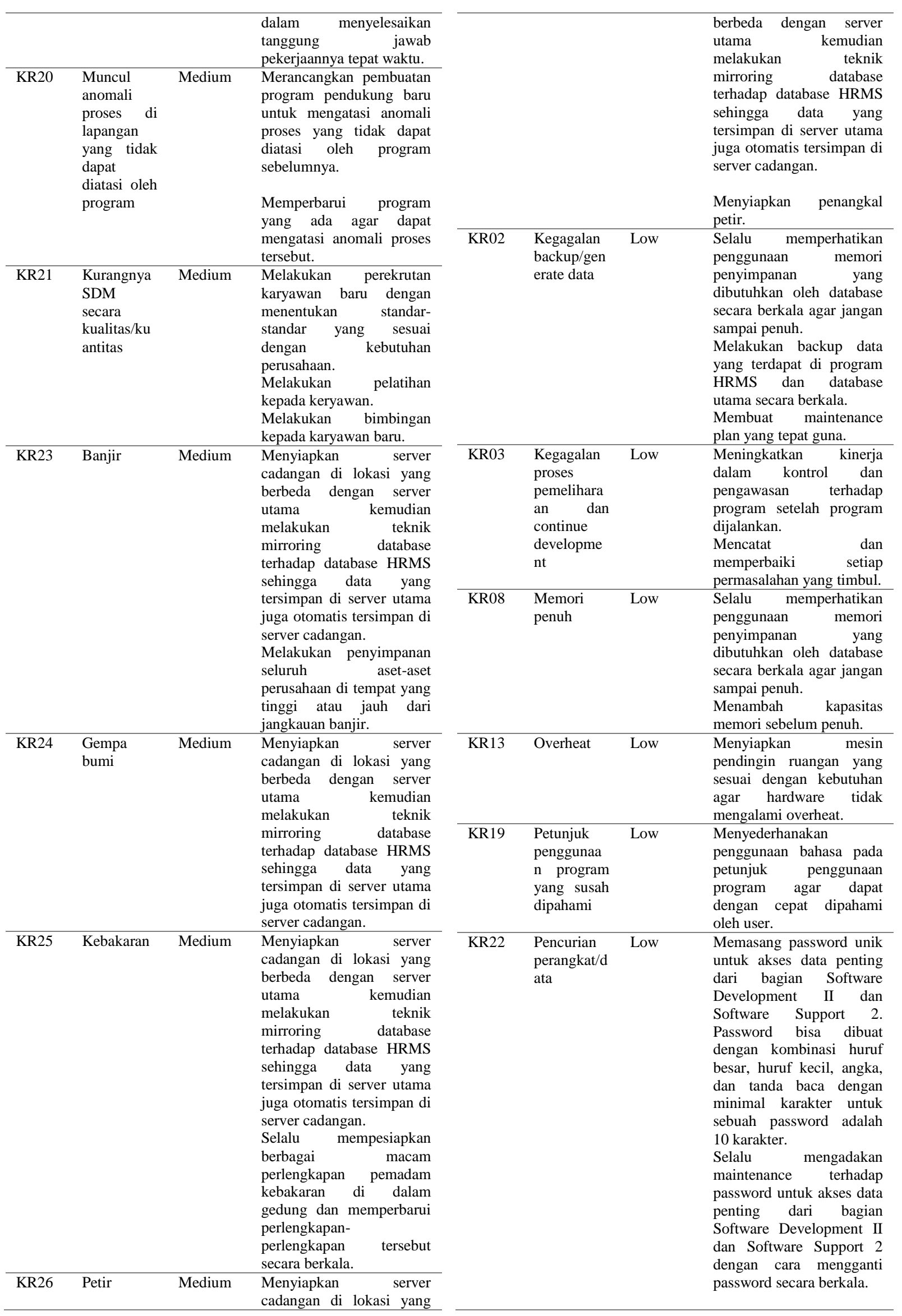

Jurnal RESTI (Rekayasa Sistem dan Teknologi Informasi) Vol. 1 No. 3 (2017) 250 - 258 


\begin{tabular}{|c|}
\hline $\begin{array}{l}\text { Menyiagakan } \\
\text { selama } 24 \text { jam. }\end{array}$ \\
\hline $\begin{array}{llr}\begin{array}{l}\text { Gedung } \\
\text { dimasuki }\end{array} & & \text { dapya } \\
\text { dengar }\end{array}$ \\
\hline menggunakan kartu akses \\
\hline karyawan perusahaan. \\
\hline $\begin{array}{l}\text { Merekam semua sudu } \\
\text { gedung perusahaan dengan } \\
\text { menggunakan CCTV. }\end{array}$ \\
\hline
\end{tabular}

\section{Kesimpulan}

\subsection{Simpulan}

Berdasarkan dari penelitian yang sudah dilakukan, analisis risiko teknologi informasi menggunakan ISO 31000 pada program Human Resource Management System (HRMS) di perusahaan retail di Indonesia dijalankan dengan menggunakan tahapan-tahapan yang dimulai dari tahap penilaian risiko yang terdiri dari tahap identifikasi risiko, tahap analisis risiko, dan tahap evaluasi risiko hingga tahap perlakuan risiko.

Dari hasil penelitian yang telah dilakukan, ditemukan terdapat 26 kemungkinan risiko yang berada di sekitar dari aset-aset yang terkait dengan program HRMS. Dari ke-26 kemungkinan risiko tersebut diketahui jika 2 kemungkinan risiko memiliki level of risk dengan tingkatan high, yaitu risiko listrik padam dan overload, 18 kemungkinan risiko yang memiliki level of risk dengan tingkatan medium, yaitu risiko data corrupt, program tidak dapat meningkatkan kualitas kinerja perusahaan, web service mati secara tiba-tiba, proses maintenance yang tidak terjadwal, hacking terhadap jaringan, server down, koneksi jaringan terputus, kerusakan hardware, dokumentasi program yang tidak lengkap, kesalahan pembuatan fungsi pada program, user interface rumit dan susah dipahami, penyelesaian program yang tidak tepat waktu, muncul anomali proses di lapangan yang tidak dapat diatasi oleh program, kurangnya SDM secara kualitas/kuantitas, banjir, gempa bumi, kebakaran, dan petir, serta 6 kemungkinan risiko yang memiliki level of risk dengan tingkatan low, yaitu risiko kegagalan backup/generate data, kegagalan proses pemeliharaan dan continue development, memori penuh, overheat, petunjuk penggunaan program yang susah dipahami, dan pencurian perangkat/data.

Sebenarnya proses penanggulangan yang dilakukan oleh perusahaan terhadap kemungkinan-kemungkinan risiko sudah berjalan, tapi proses penanggulangan yang dilakukan tersebut hanya berdasarkan dari pengalaman saja tanpa dilengkapi dengan dokumentasi yang baik terkait dengan manajemen risiko perusahaan. Dengan adanya penelitian ini diharapkan dapat digunakan sebagai alat bantu bagi pemangku kebijakan dari perusahaan untuk dapat menyusun dokumentasidokumentasi terkait dengan manajemen risiko perusahaan di kemudian hari.

\subsection{Saran}

Setelah melakukan penelitian analisis risiko teknologi informasi menggunakan ISO 31000 pada program Human Resource Management System (HRMS) di perusahaan retail di bagian Software Development II dan Software Support 2 ini, untuk peneliti di kemudian hari bisa melaksanakan penelitian dengan cakupan penelitian yang lebih luas sehingga temuan-temuan analisis risiko yang ada nantinya bisa dimanfaatkan oleh pemangku kebijakan untuk menyusun dokumentasi terkait dengan manajemen risiko perusahaan dan dokumentasi tersebut bisa diaplikasikan tidak hanya pada bagian-bagian tertentu saja melainkan bisa diaplikasikan untuk ke seluruh bagian dari perusahaan yang ada.

\section{Daftar Rujukan}

[1] Nice, F. L., Imbar, R. V., 2016, Analisis Risiko Teknologi Informasi pada Lembaga Penerbangan dan Antariksa Nasional (LAPAN) pada Website SWIFTS Mengunakan ISO 31000, http://journal.uc.ac.id/index.php/JUISI/article/view/237, diakses tanggal 22 September 2017.

[2] Husein, G. M., Imbar, R. V., 2015, Analisis Manajemen Risiko Teknologi Informasi Penerapan pada Document Management System di PT. Jabar Telematika (JATEL), http://jutisi.maranatha.edu/index.php/jutisi/article/view/368, diakses tanggal 22 September 2017.

[3] Harimurti, F., 2006, Manajemen Risiko, Fungsi dan Mekanismenya, Jurnal Ekonomi dan Kewirausahaan, no. 1, vol. 6 , hal 105-112.

[4] Hasibuan, Z. A., 2007, Metodologi Penelitian pada Bidang Ilmu Komputer dan Teknologi Informasi, http://mhs.uks.ac.id/.../BUKU-METODE-PENELITIAN-PADABIDANG-IKOM-TI-ZAINA..., diakses tanggal 22 September 2017.

[5] Amriani, Selvi, 2012, Analisis Risiko Teknologi Informasi Berbasis ISO 31000/31010 Studi Kasus: Lembaga Penelitian Perguruan http://majour.maranatha.edu/index.php/jurnal-sisteminformasi/article/view/996, diakses tanggal 13 November 2017.

[6] Joint Australian New Zealand International Standard, 2009, AS/NZS ISO 31000:2009 Risk Management - Principles and Guidelines.

[7] Dali. Alex, 2012, "ISO 31000 Risk Management" The Golden Standard, vol. 45 , no. 5 .

[8] Knight, K. W., 2012, ISO 31000:2009; ISO/IES 31010 \& ISO Guide 73:2009 International Standards for the Management of Risk, Presentation.

[9] Putra, I Gusti B. W., Muqtadiroh, F. A., Nisafani, A. S., 2016, Analisis Risiko pada Implementasi Perangkat Lunak di Lingkungan Pemerintahan dengan Menggunakan Framework ISO 31000:2009, http://repository.its.ac.id/48855, diakses tanggal 16 November 20 